ISSN: 2302-8556

\title{
Analisis Reaksi Pasar Terhadap Pengumuman Akuisisi Pada Perusahaan Akuisitor Yang Terdaftar di BEI
}

\author{
Ika Putri Adnyani ${ }^{1}$ \\ Gayatri $^{2}$ \\ ${ }^{1}$ Fakultas Ekonomi dan Bisnis Universitas Udayana (Unud), Bali Indonesia \\ email: ikaputriadnyani@gmail.com/ Telp: +62 81936220543 \\ ${ }^{2}$ Fakultas Ekonomi dan Bisnis Universitas Udayana (Unud), Bali Indonesia
}

\begin{abstract}
ABSTRAK
Secara teori, pengumuman akuisisi seharusnya memiliki informasi yang dapat berpengaruh pada pasar, akuisisi yang dilakukan perusahaan dapat ditanggapi sebagai informasi positif atau informasi negatif oleh investor. Penelitian ini dilakukan pada seluruh perusahaan akuisitor yang melakukan akuisisi yang terdaftar di Bursa Efek Indonesia periode 20112016. Metode pengambilan sampel menggunakan purposive sampling. Jumlah sampel penelitian ini adalah sebanyak 50 perusahaan. Reaksi pasar pada penelitian ini menggunakan proksi abnormal return dan volume perdagangan saham. Pengujian kandungan informasi akan dilakukan dengan melihat perbedaan cumulative abnormal return dan rata-rata volume perdagangan saham lima hari sebelum dan lima hari setelah pengumuman akuisisi. Teknik analisis data yang digunakan adalah uji paired sample t-test. Berdasarkan hasil pengujian, ditemukan terdapat perbedaan signifikan pada abnormal return perusahaan akuisitor sebelum dan sesudah pengumuman akuisisi. Namun tidak terdapat perbedaan volume perdagangan saham perusahaan akuisitor sebelum dan sesudah pengumuman akuisisi.
\end{abstract}

Kata kunci: Akuisisi, pasar modal, abnormal return, volume perdagangan saham

\begin{abstract}
Based on the theory, the acquisition announcement should give the information that can affect the market, the acquisitions that made by the company can be addressed as positive information or negative information by investors. This research is conducted on all acquisition companies that conduct acquisitions listed on Indonesia Stock Exchange 20112016 period. Sampling method using purposive sampling. The number of samples of this research is 50 companies. The market reaction in this study used abnormal return and trading volume activity. The testing of information content will be done by looking at differences in cumulative abnormal return and the average trading volume of shares five days before and five days after the announcement of the acquisition. Data analysis technique used is paired sample t-test. Based on the test results, found there are significant differences in the abnormal return of the acquirer company before and after the announcement of the acquisition. However, there is no difference in trading volume activity of the acquirer's stock before and after the acquisition announcement

Keywords: Acquisitions, stock market, abnormal return, trading volume activity
\end{abstract}

\section{PENDAHULUAN}

Pasar modal adalah salah satu faktor penting dalam perekonomian suatu negara.

Menurut Bahtera (2014:22), pasar modal memiliki makna yang secara prinsip memiliki kesamaan dengan pasar pada umumnya, yakni sebagai tempat 
bertemunya penjual dan pembeli yang dalam konteks pasar modal dimana penjual adalah pihak yang memerlukan modal (emiten) dan pembeli yaitu pihak yang memberikan modal (investor). Dalam usaha untuk memenuhi keperluan dananya, perusahaan melakukan penerbitan obligasi (surat pernyataan hutang perusahaan) dan juga penerbitan saham (hak kepemilikan atas perusahaan) dimana saham adalah instrumen keuangan yang oleh investor baik perorangan maupun institusi paling banyak memperjualbelikan di pasar modal.

Menurut Hidayat (2013), pasar modal merupakan suatu instrumen ekonomi yang tak dapat lepas dari berbagai pengaruh lingkungan, baik dari segi lingkungan ekonomi maupun lingkungan non-ekonomi. Peristiwa-peristiwa yang mempunyai kandungan informasi dapat memengaruhi pasar modal. Reaksi yang terjadi pada pasar modal merupakan respon investor dalam melakukan sebuah investasi. Jika seluruh informasi yang memiliki kaitan dengan perusahaan terefleksi pada harga saham perusahaan tersebut maka pasar tersebut dikatakan efisien (Brigham dan Ehrhardt, 2011). Semakin cepat suatu informasi baru merefleksikan harga saham di sekuritas, maka akan semakin pasar modal tersebut dikatakan efisien. Hal ini sejalan dengan kondisi ideal pasar efisien dan konsep dasar efisiensi, maka secara informasional Fama (1970) mengklasifikasikan pasar modal yang efisien menjadi tiga bentuk pasar efisien (Fama, 1970) yaitu: Efisiensi pasar bentuk lemah (weak form), Efisiensi pasar bentuk semi kuat (semi-strong form), dan Efisiensi pasar bentuk kuat (strong form). Fudji (2012) menyatakan bahwa teori efisien pasar modal di Indonesia untuk model efisiensi semi kuat (semi strong form) sudah 
efisien, hal ini disebabkan pengumuman kenaikan dan penurunan pendapatan emiten dapat memengaruhi perubahan harga saham perusahaan di pasar modal.

Pasar efisien dalam bentuk lemah dapat berarti semua informasi historis akan terefleksi dalam harga saham yang terbentuk saat ini. Pasar efisien dalam bentuk setengah kuat merupakan bentuk efisiensi pasar yang lebih komprehensif karena bentuk ini harga saham tidak hanya dipengaruhi oleh data pasar, namun juga dipengaruhi oleh semua informasi yang telah dipublikasikan. Pasar efisien dalam bentuk kuat yaitu semua informasi baik yang terpublikasi maupun tidak dipublikasikan, sudah tercermin dalam harga sekuritas saat ini. Dengan demikian tidak seorang investor pun yang dapat memeroleh abnormal return dengan memanfaatkan informasi yang ia miliki.

Investor akan berupaya untuk mencari berbagai informasi yang relevan terkait dengan emiten sebelum mengambil tindakan investasinya apakah hal itu membeli atau menjual saham untuk dapat mengurangi risiko yang tidak diinginkan dan memperoleh return sesuai yang diharapkan. Informasi yang didapat oleh investor akan memiliki nilai jika informasi tersebut ditanggapi oleh investor dengan tindakan transaksi jual beli saham dan akan tergambarkan pada perubahan harga saham emiten yang tentunya akan mengubah return yang akan diperoleh investor dan juga tercermin pada perubahan volume perdagangan saham.

Informasi yang diperoleh investor dapat berupa suatu pengumuman atas kebijakan yang diambil oleh manajemen perusahaan. Kondisi atas persaingan usaha yang semakin ketat menuntut manajemen perusahaan agar selalu dapat 
Ika Putri Adnyani dan Gayatri. Analisis...

mengembangkan strategi perusahaan untuk dapat bertahan atau bahkan berkembang lebih cepat. Strategi ini diharapkan bisa diterapkan dalam perubahan lingkungan yang telah, sedang dan akan terjadi di perusahaan agar perusahaan dapat mempertahankan eksistensinya serta dan memperbaiki kinerjanya. Salah satu dari keputusan strategis yang dapat dilakukan perusahaan dalam mempertahankan eksistensi atau memperbaiki kinerjanya adalah keputusan untuk melakukan kombinasi bisnis antara lain merger atau akuisisi.

Merger merupakan penyerapan dari suatu perusahaan oleh perusahaan lain. Merger merupakan penggabungan usaha pada suatu nama perusahaan dengan syarat salah satu perusahaan harus berbentuk PT. Jika dua perusahaan, A dan B, melakukan merger, maka hanya akan ada satu perusahaan saja, yaitu A atau B. Pada sebagian besar kasus merger, perusahaan dengan kapitalisasi yang lebih besar yaang dipertahankan hidup dan tetap mempertahankan nama perusahannya dan status hukumnya, sedangkan perusahaan yang ukurannya lebih kecil (perusahaan yang dimerger) akan menghentikan aktivitas atau dibubarkan sebagai badan hukum.

Sedangkan akuisisi merupakan suatu pengambilalihan kepemilikan dan kontrol manajemen oleh suatu perusahaan terhadap perusahaan yang lain. Akuisisi memiliki perbedaaan dengan merger dimana akuisisi tidak menyebabkan entitas atau pihak lain bubar sebagai badan hukum. Perusahaan-perusahaan yang diakuisisi secara yuridis masih tetap berdiri dan beroperasi secara independen, namun telah terjadi pengalihan pengendalian oleh pihak manajemen dalam perusahaan tersebut. 
Akuisisi sebagai salah satu keputusan strategis perusahaan akan membawa dampak bagi perusahaan bidder (perusahaan yang memerger atau mengakuisisi) dan perusahaan target (perusahaan yang dimerger atau diakuisisi). Dampak yang ditimbulkan oleh akuisisi yaitu terhadap kinerja perusahaan, baik kinerja operasionalnya yang berupa profitabilitas dan likuiditas, maupun kinerja saham yang berupa return yang kemungkinan negatif (penurunan kinerja), atau mungkin saja positif (peningkatan kinerja), yang mungkin dalam jangka pendek, mungkin pula dalam jangka panjang (Pujonggo, 2004). Secara kuantitas, aktivitas akuisisi mengalami peningkatan yang signifikan seiring dengan semakin populernya istilah merger dan akuisisi itu sendiri di kalangan pelaku usaha. Akuisisi adalah sebuah langkah yang diambil dalam rangka restrukturisasi perusahaan yang diyakini akan dapat mendatangkan kemakmumran serta keuntungan dalam waktu singkat.

Sebelumnya, aktivitas merger dan akuisisi bukan merupakan suatu fenomena baru dalam dunia usaha. Kegiatan merger dan akuisisi ini mulai marak dilakukan perusahaan multinasional di Amerika dan Eropa sejak tahun 1960-an sedangkan kegiatan merger dan akuisisi di Indonesia telah dikenal secara sektoral khususnya di bidang perbankan sebelum berlakunya Undang-Undang No.1 Tahun 1995 tentang Perseroan Terbatas (Kuncoro, 2014). Berbagai fenomena merger dan/atau akuisisi di Indonesia berupa informasi mengenai kegiatan merger dan akuisisi di Indonesia sudah mulai terjadi pada tahun 1970-an, yang perkembangannya terus berlangsung sampai sekarang. Menurut Kuncoro (2014), istilah merger dan akuisisi ini menjadi semakin populer setelah adanya merger 
empat bank besar milik pemerintah pada tahun 1998 yang bergabung akibat adanya krisis yang akhirnya menghasilkan Bank Mandiri.

Krisis ekonomi yang terjadi di daratan Eropa dan Amerika Serikat di tahun 2008-2009 turut memberi dampak perekonomian secara global dan juga terhadap perekonomian Indonesia. Menurut Komisi Pengawas Persaingan Usaha (KPPU), krisis yang terjadi saat itu menyebabkan tren peningkatan efisiensi di kalangan para pelaku usaha, yang pada akhirnya mengakibatkan gelombang merger dan akuisisi yang terjadi di Indonesia. KPPU mencatat gelombang merger dan akuisisi di Indonesia terus mengalami peningkatan. Tahun 2010 dan 2011 merupakan tahun-tahun dimana gelombang merger dan akuisisi melanda Indonesia. Puncaknya pada tahun 2013, jumlah notifikasi atau pemberitahuan mengenai merger dan akuisisi yang masuk ke KPPU melebihi tahun-tahun sebelumnya yaitu sejumlah 69 notifikasi dan diperkirakan akan terus meningkat di masa mendatang (Nuviani, 2013).

Berdasarkan data KPPU, peristiwa merger dan akuisisi yang terjadi di Indonesia cenderung didominasi oleh perusahaan pengakuisisi (akuisitor) yang telah go public dengan perusahaan target atau diakuisisi yang belum go public, dengan perbandingan perusahaan yang melakukan tindakan akuisisi lebih banyak daripada perusahaan yang melakukan tindakan merger. Frekuensi pelaksanaan aktivitas merger dan akuisisi yang dilakukan perusahaan akuisitor di Indonesia cukup tergolong tinggi. Fenomena tersebut ditandai oleh banyaknya perusahaan yang melakukan tindakan merger atau akuisisi lebih dari sekali dalam satu tahun. Kecenderungan yang terjadi di Indonesia, pola aktivitas merger dan akuisisi lebih 
banyak dilakukan disebabkan karena pemilik perusahaan lebih nyaman dengan kepemilikan saham pribadi dalam jumlah besar (Malau, 2016). Kuncoro (2014) menyebutkan alasan utama perusahaan-perusahaan di Indonesia menggabungkan usahanya adalah untuk back door listing yaitu pendaftaran saham tanpa melakukan IPO (Initial Public Offering) dari anak perusahaan target oleh perusahaan publik.

Secara teori, pengumuman akuisisi seharusnya memiliki informasi yang dapat berpengaruh pada pasar, akuisisi yang dilakukan perusahaan dapat ditanggapi sebagai suatu informasi positif atau negatif oleh investor. Informasi positif terjadi jika perusahaan yang melakukan akuisisi bertujuan untuk melakukan ekspansi usahanya atau investasi. Sedangkan sinyal negatif diartikan oleh investor ketika perusahaan melakukan akuisisi untuk tujuan mencegah kebangkrutan.

Investor menganalisis pengumuman akuisisi memiliki kandungan informasi yang sangat berharga akan memicu pergerakan pasar yang menyebabkan perubahan harga saham yang dapat diukur dengan menggunakan menggunakan return atau dengan abnormal return. Investor akan mendasarkan keputusan investasinya pada berbagai informasi yang telah dimilikinya. Para investor akan menganggap suatu informasi akan memiliki nilai jika keberadaan informasi tersebut mampu membuat para investor melakukan tindakan transaksi di pasar atau dengan kata lain jika pengumuman pelaksanaan akuisisi yang dikeluarkan emiten memiliki kandungan informasi yang cukup, maka pengumuman itu akan mempengaruhi preferensi investor dalam pembuatan keputusan investasinya. 
Ika Putri Adnyani dan Gayatri. Analisis...

Ada atau tidaknya pengaruh kandungan informasi tersebut dapat dilihat dari ada tidaknya abnormal return yang signifikan di sekitar tanggal pelaksanaan akuisisi. Abnormal return merupakan selisih antara return yang sesungguhnya dengan return ekspektasi atau yang diharapkan. Abnormal return diperoleh dengan membandingkan return yang diharapkan dengan return sesungguhnya. Selain abnormal return, reaksi pasar dapat juga diukur melalui pergerakan perdagangan saham di pasar modal menggunakan variabel volume perdagangan saham (Aryasa, 2016). Dimana perubahan volume perdagangan saham merefleksikan keputusan investasi investor karena menunjukkan adanya aktivitas perdagangan saham di pasar modal.

Husnan (2009) menyatakan teori sinyal atau signalling theory mengasumsikan bahwa suatu kebijakan atau keputusan yang diambil oleh emiten, pemerintah, atau investor pada prinsipnya akan dianggap sebagai informasi yang memberikan sinyal atau pertanda bagi pasar tentang tren atau kecenderungan di masa yang akan datang. Menurut Tandelilin (2010:565), berita baik akan direspon positif oleh pasar yang dicerminkan dengan adanya abnormal return yang positif. Begitu sebaliknya dengan berita buruk akan direspon negatif oleh pasar yang dicerminkan dengan adanya abnormal return yang negatif. Akuisisi merupakan suatu corporate action yang memiliki hubungan yang erat dengan teori sinyal dimana teori sinyal merupakan hasil dari corporate action. Tindakan akuisisi mempunyai nilai informatif bagi investor sehingga hal tersebut dapat mempengaruhi kebijakan investasi dalam bentuk perubahan harga saham karena adanya peningkatan atau penurunan transaksi (Sutrisno, 2001). 
Brigham dan Houston (2011) mengatakan bahwa signalling theory menunjukkan adanya informasi asimetri antara manajemen perusahaan dengan pihak-pihak lain. Informasi asimetri adalah situasi di mana manajemen memiliki informasi yang berbeda (lebih baik) mengenai prospek perusahaan dibandingkan dengan informasi yang dimiliki oleh investor dan kreditur. Hal ini akan menyebabkan pasar bereaksi dan memberikan sinyal negatif jika informasi yang diperoleh kurang lengkap dan tidak akurat. Sebaliknya jika informasi dari perusahaan jelas dan akurat pasar akan bereaksi positif dengan melakukan investasi pada perusahaan dan secara otomatis meningkatkan nilai perusahaan tersebut.

Teori pasar efisien (Efficient Market Hypothesis) mengasumsikan bahwa saham yang diperdagangkan akan merefleksikan segala informasi yang mungkin terjadi secara cepat dan juga akurat (Ang, 2010). Konsep ini menyatakan bahwa para investor selalu memasukkan faktor informasi yang diberikan dalam keputusan investasi mereka sehingga terefleksi pada harga yang mereka transaksikan. Jadi harga yang berlaku di pasar sudah tergantung faktor informasi tersebut. Harga saham mengandung tiga faktor diantaranya merefleksikan semua informasi yang sifatnya historis, merefleksikan kejadian yang telah diumumkan tetepi belum dilaksanakan, dan merefleksikan prediksi atas informasi yang akan datang.

Bentuk pasar efisien dapat ditinjau tidak hanya dari segi ketersediaan informasinya saja, tetapi juga dapat dilihat dari kecanggihan pelaku pasar dalam pengambilan keputusan berdasarkan analisis dan informasi yang tersedia 
(Jogiyanto, 2000). Pasar efisien yang ditinjau hanya dari sudut pandang informasinya saja disebut efisiensi pasar secara infomasi (informationally efficient market).

Kunci utama untuk mengukur pasar modal efisien adalah hubungan antara sekuritas dengan informasi. Dimana informasi yang dapat digunakan untuk menilai pasar efisien adalah informasi yang lama, informasi yang sedang dipublikasikan atau semua informasi termasuk informasi privat. Fama dalam Jogiyanto (2008) menyajikan tiga macam bentuk utama dari efisiensi pasar berdasarkan ketiga macam bentuk informasi, yaitu: Efisiensi pasar bentuk lemah (weak form), Efisiensi pasar bentuk setengah kuat (semistrong form), Efisiensi pasar bentuk kuat (strong form). Salah satu jenis informasi privat adalah jenis informasi yang berasal dari orang dalam (insider information) yang mempunyai akses atas informasi berharga mengenai keputusan penting yang telah direncanakanoleh perusahaan. Sehingga dengan modal informasi tersebut mereka melakukan analisa dan mengambil posisi transaksi yang sesuai. Pada saat mengumumkan perseroan tersebut dikeluarkan, maka informasi tersebut menjadi tersedia bagi masyarakat dan akan mendongkrak harga saham tersebut. Informasi privat yang demikian mampu memberikan keuntungan abnormal yang konsisten bagi para pemodal yang memiliki informasi tersebut.

Akuisisi secara harfiah memiliki makna membeli atau mendapatkan sesuatu/obyek untuk ditambahkan pada sesuatu/obyek yang telah dimiliki sebelumnya. Dalam terminologi bisnis, akuisisi dapat diartikan sebagai 
pengambilalihan kepemilikan atau pengendalian atas saham atau aset suatu perusahaan oleh perusahaan lain (Nugroho, 2010).

Peraturan Pemerintah Republik Indonesia No. 57 Tahun 2010 mendefinisikan akuisisi sebagai suatu perbuatan hukum yang dilakukan oleh pelaku usaha untuk mengambilalih saham badan usaha yang mengakibatkan beralihnya pengendalian atas badan usaha tersebut. Dalam Pernyataan Standar Akutansi Keuangan (PSAK) No.22, akuisisi dinyatakan sebagai suatu bentuk pengambilalihan kepemilikan perusahaan oleh pihak pengakuisisi (perusahaan bidder), sehingga akan mengakibatkan berpindahnya kendali atas perusahaan yang diambil alih (perusahaan target) tersebut. Kendali perusahaan yang dimaksud adalah kekuatan untuk mengatur kebijakan keuangan dan operasi perusahaan, mengangkat dan memberhentikan manajemen, dan/atau mendapat hak suara mayoritas dalam rapat redaksi.

Pengendalian ini memberikan manfaat kepada perusahaan bidder. Akuisisi berbeda dengan merger karena akuisisi tidak mengakibatkan pihak lain bubar sebagai entitas hukum. Perusahaan-perusahaan yang terlibat dalam akuisisi secara hukum masih tetap beroperasi secara independen tetapi telah terjadi pengalihan pengendalian kepada pihak pengakuisisi.

Moin (2010) membagi akuisisi menjadi dua jenis, yaitu akuisisi saham dan akuisisi aset. Akuisisi saham yaitu akuisisi yang terjadi ketika pemilik saham (target) menjual sahamnya kepada pembeli/pengakuisisi. Pada peristiwa ini, biasanya dilakukan dengan terlebih dahulu melakukan negosiasi dan penawaran dengan pihak manajemen atau dewan direksi perusahaan target dan selanjutnya 
perusahaan yang diakuisisi akan menjadi perusahaan anak dimana kewajiban atau hutang target yang ada ditanggung oleh pemilik baru. Sedangkan, akuisisi aset adalah akuisisi yang dapat dilakukan dengan membeli sebagian atau keseluruhan aktiva atau aset perusahaan lain, dimana kewajiban atau hutang target yang ada ditanggung oleh perusahaan target. Jika pembelian tersebut hanya sebagian dari aktiva perusahaan maka hal ini dinamakan akuisisi parsial.

Event study atau studi peristiwa merupakan studi yang mempelajari reaksi pasar terhadap satu peristiwa (event) yang informasinya dipublikasikan sebagai suatu pengumuman (Jogiyanto, 2010:555). Event study merupakan satu metode untuk menganalisis perubahan harga saham di seputar tanggal pengumuman perusahaan atau peristiwa tertentu. Event study bertujuan untuk menilai ada atau tidaknya muatan informasi di dalam satu peristiwa yang dalam hal ini pengumuman akuisisi dan juga menguji hipotesis efisiensi pasar bentuk setengah kuat.

Suatu event dikatakan mempunyai muatan informasi jika pasar bereaksi pada waktu pengumuman atau peristiwa diterima oleh pasar. Reaksi ditunjukkan dengan adanya perubahan harga dan adanya abnormal return pada sekuritas yang bersangkutan (Nanggala, 2009:36). Beberapa penelitian sebelumnya menyebutkan bahwa akuisisi memiliki kandungan informasi yang membuat pasar bereaksi antara lain, Rumondang (2010) meneliti tentang pengaruh pengumuman merger dan akuisisi bagi perusahaan pengakuisisi di Bursa Efek Indonesia. Hasil penelitian tersebut menyatakan adanya abnormal return yang signifikan bagi perusahaan yang mengakuisisi di sekitar tanggal pengumuman. 
Maryati (2012) melakukan penelitian mengenai pengaruh pengumuman merger terhadap harga dan volume perdagangan saham memperoleh hasil pengujian hipotesis menunjukkan bahwa hasil pengujian dengan periode event window 11 hari menunjukkan bahwa kumulatif rata-rata TVA setelah event atau peristiwa lebih besar dibandingkan dengan sebelum event dan pengumuman merger memiliki pengaruh yang signifikan pada harga saham dan juga volume perdagangan saham.

Astria (2013) meneliti dampak dari pengumuman merger dan akuisisi terhadap abnormal return saham pada perusahaan akuisitor dari tahun 2006 sampai tahun 2008. Hasil pengujian dari penelitian tersebut menunjukkan bahwa ditemukan perbedaan yang signifikan abnormal return pada saat periode sebelum dan sesudah pengumuman merger dan akuisisi.

Namun dalam beberapa penelitian lain ditemukan hasil yang tidak sama dengan penelitian tersebut diatas, diantaranya Edward (2012) yang melakukan penelitian mengenai pengaruh pengumuman merger dan akuisisi terhadap abnormal return dan volume perdagangan saham di sekitar tanggal pengumuman. Hasil pengujian hipotesisnya menyatakan bahwa tidak terdapat perbedaan abnormal return dan volume perdagangan saham yang signifikan pada saat periode sekitar pengumuman, namun terdapat perbedaan volume perdagangan saham pada perusahaan berkapitalisasi besar.

Rusnanda (2013) melakukan sebuah penelitian tentang pengaruh pengumuman merger dan akuisisi terhadap abnormal return saham pada bank umum di BEI, dimana hasil penelitian menunjukkan bahwa tidak ditemukan 
perbedaan rata-rata abnormal return yang signifikan periode sebelum dan sesudah peristiwa merger dan akuisisi. Berdasarkan kesimpulannya, hal tersebut disebabkan oleh informasi yang telah bocor sebelum pengumuman, para pelaku usaha yang sudah terbiasa dengan peristiwa merger dan akuisisi dan para pelaku usaha belum sepenuhnya mempercayai informasi yang muncul baik ekonomi maupun non ekonomi. Priyambodo (2015) melakukan penelitian tentang pengujian kandungan informasi terhadap peristiwa merger dan akuisisi, dimana hasil penelitian ini membuktikan bahwa peristiwa merger dan akuisisi tidak memiliki kandungan informasi. Hal ini disebabkan karena pengumuman merger dan akuisisi yang dilakukan entitas telah diidentifikasi oleh pasar.

Dananjaya (2015) yang melakukan suatu studi komparatif abnormal return sebelum dan sesudah merger pada perusahaan di BEI menyebutkan bahwa hasil penelitian menyatakan bahwa ditemukan tidak ada perbedaan yang signifikan pada abnormal return periode sebelum dan sesudah pengumuman merger dan akuisisi. Dan dari hasil penelitiannya, hal ini disebabkan oleh kebocoran informasi mengenai merger dan akuisisi yang diindikasikan dengan terjadinya peningkatan abnormal return yang sangat tinggi pada saat t-2 yang berarti pasar bereaksi terlebih dahulu.

Restanti (2015) juga meneliti mengenai pengaruh merger dan akuisisi pada abnormal return, volume perdagangan saham, dan risiko sistematis. Penelitiannya menyatakan bahwa ditemukan perbedaan abnormal return yang tidak signifikan namun terdapat perbedaan signifikan pada TVA pada sebelum maupun sesudah pengumuman merger dan akuisisi. 
Pasar modal yang efisien akan menangkap informasi yang dikeluarkan oleh perusahaan sehingga akan mempengaruhi harga saham tersebut di pasar. Sinyal positif akan membuat pasar merespon positif informasi dari emiten sedangkan sinyal negatif akan membuat pasar merespon negatif informasi tersebut. Beberapa penelitian sebelumnya yang menguji tentang pengaruh pengumuman merger dan akuisisi dengan abnormal return menunjukkan bahwa pasar bereaksi signifikan terhadap peristiwa merger dan akuisisi, diantaranya Wibowo dan Pakereng (2001), Kards, et al. (2011), Rani dan Kadav (2013), Asti Rumondang (2010), Ulfi Maryati (2012), Nike Astria (2013), Epriyeni dan Kharlina (2013) dan Dhitta Ayu Lestari (2014). Namun terdapat penelitian yang bertentangan dengan teori tersebut diantaranya Shah dan Arora (2014), Akben dan Altiok Yilmaz (2011), Van Dijk (2011), Rusnanda dan Pardi (2013), Dananjaya dan Wiagustini (2015), Priyambodo (2015), dan Malau (2016). Berdasarkan hal tersebut dirumuskan hipotesis yaitu:

$\mathrm{H}_{1}$ : Terdapat perbedaan abnormal return sebelum dan sesudah pengumuman akuisisi pada perusahaan akuisitor

Menurut Setyawan (2006), volume perdagangan saham adalah suatu instrumen yang dapat digunakan untuk melihat reaksi pasar terhadap informasi dengan melalui parameter pergerakan volume perdagangan di pasar modal. TVA (Trading Volume Activity) merupakan jumlah saham yang diperdagangkan pada periode tertentu, biasanya harian. Ditinjau dari segi fungsinya, maka dapat dikatakan bahwa TVA merupakan variasi dari studi peristiwa (event study). Penelitian sebelumnya mengungkapkan adanya pengaruh pengumuman merger dan akuisisi dengan volume perdagangan saham, diantaranya Rahmayanti (2015), 
dan Restanti (2015). Sedangkan terdapat penelitian yang berlawan dengan hasil penelitian tersebut, diantaranya Edward (2012), Maryati 2012), dan Pratama (2015). Berdasarkan hal tersebut, maka dirumuskan hipotesis yaitu:

$\mathrm{H}_{2}$ : Terdapat perbedaan volume perdagangan saham sebelum dan sesudah pengumuman akuisisi pada perusahaan akuisitor

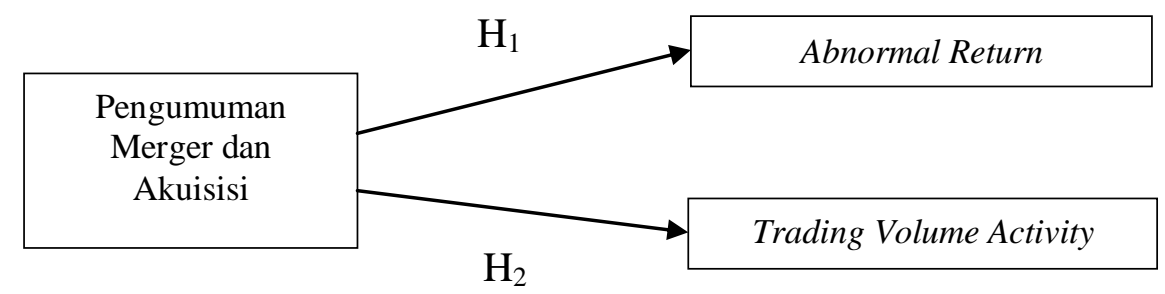

Gambar 1. Kerangka Konsep Penelitian.

\section{METODE PENELITIAN}

Metode pendekatan yang digunakan di dalam penelitian ini adalah pendekatan kuantitatif. Metode yang digunakan adalan metode arsip atau metode dokumentasi dimana peneliti melakukan pengumpulan data yang diperoleh dari dokumen mengenai data-data historis. Penelitian ini dilakukan bersumber dari website Bursa Efek Indonesia yaitu ww.idx.co.id, www.finance.yahoo.com, www.ticmi.co.id, www.kppu.go.id, buku-buku, skripsi-skripsi dan jurnal-jurnal yang berkaitan dengan penelitian ini.

Lokasi penelitian ini dilakukan di Bursa Efek Indonesia (BEI) dengan mengakses web site www.idx.co.id dan juga www.finance.yahoo.com serta mengunduh laporan keuangan auditan perusahaan yang melakukan merger dan akuisisi sebagai data di tahun 2011-2016. Abnormal return adalah variabel yang diukur dengan cara menyelisihkan return sesungguhnya yang terjadi dengan return ekspektasian (Jogiyanto, 2010:580). Penelitian ini menggunakan Market 
Adjusted Model untuk dapat mengestimasi return ekspektasinya. Adapun langkahlangkah untuk menghitung abnormal return adalah sebagai berikut.

a. Return Individual (Rit)

$$
R_{i t}=\frac{P_{t}-P_{t-1}}{P_{t-1}}
$$

Keterangan:

$\mathrm{R}_{\mathrm{it}}$ : return individual saham i pada saat $\mathrm{t}$

$\mathrm{P}_{\mathrm{t}}$ : harga penutupan saham i pada saat $\mathrm{t}$

$\mathrm{P}_{\mathrm{t}-1}$ : harga penutupan saham i pada saat $\mathrm{t}-1$

b. Return Pasar (Rmt)

$$
R m_{t}=\frac{I H S G_{t}-I H S G_{t-1}}{I H S G_{t-1}}
$$

Keterangan:

$\mathrm{Rm}_{\mathrm{t}} \quad$ : tingkat return pasar pada saat $\mathrm{t}$

IHSG $_{\mathrm{t}} \quad$ : Indeks Harga Saham Gabungan pada saat t

IHSG $_{\mathrm{t}-1}$ : Indeks Harga Saham Gabungan pada saat t- 1

c. Abnormal return

$$
A R_{t}=R_{i t}-R m_{t}
$$

Keterangan:
$\mathrm{AR}_{\mathrm{t}}$
: abnormal return saham i saat $\mathrm{t}$
$\mathrm{R}_{\mathrm{it}}$ : return individual saham i saat $\mathrm{t}$
$\mathrm{Rm}_{\mathrm{t}}$ : tingkat return pasar saham saat $\mathrm{t}$

Volume perdagangan saham adalah variabel yang dihitung dengan Rumus yang digunakan untuk menghitung Volume Perdagangan Saham (Trading Volume Activity) adalah:

a. Menghitung perubahan volume perdagangan saham

$$
T V A=\frac{\text { jumlah saham yang diperdagangkan pada perĩode pertentu }}{\text { jumlah saham yang beredar pada perióode tertentu }}
$$

b. Menghitung rata-rata volume perdagangan saham

$$
\bar{X} T V A=\frac{\sum_{i=1}^{n} T V A_{I}}{n}
$$


Keterangan:

$\bar{X} T V A=$ rata-rata volume perdagangan saham

$\mathrm{TVA}_{\mathrm{i}}=$ Trading Volume Activity saham i yang diakumulasi dari periode peristiwa sebelum ( $\mathrm{t}-5)$ sampai $(\mathrm{t}-1)$ atau periode peristiwa setelah $(\mathrm{t}+1)$ sampai $(\mathrm{t}+5)$

$\mathrm{n} \quad=$ jumlah hari pengamatan periode peristiwa sebelum $(\mathrm{t}-5)$ sampai $(\mathrm{t}-1)$ dan periode peristiwa setelah $(\mathrm{t}+1)$ sampai $(\mathrm{t}+5)$

Pengumuman akuisisi merupakan variabel dalam penelitian ini yang diukur menggunakan periode peristiwa. Periode pengamatan yang digunakan dalam penelitian ini adalah periode peristiwa selama 11 hari yaitu 5 hari sebelum pengumuman (H-5), 1 hari saat pengumuman (event date, $\mathrm{H}=0$ ) dan 5 hari sesudah tanggal pengumuman $(\mathrm{H}+5)$. Di dalam penentuan lamanya, periode peristiwa tidak memiliki standar bakunya. Pemilihan periode peristiwa dalam penelitian ini dipilih karena diharapkan pergerakan harga saham dalam rentang periode peristiwa terjadi tidak dipengaruhi peristiwa lain. Periode pengamatan selama 11 hari dipilih sebab rentang waktu tersebut dianggap cukup, karena menurut McWilliams dan Siegel (1997), jarak event window yang terlalu panjang akan dapat menimbulkan dua permasalahan. Pertama, akan dapat mengurangi kekuatan uji statistic yang dilakukan dan mengakibatkan kesalahan dalam melakukan penarikan kesimpulan tentang signifikansi suatu event. Kedua, semakin panjang periode pengamatan akan menyebabka semakin sulitnya mengisolir jendela peristiwa dari confounding effect atau efek pengganggu.

\section{HASIL DAN PEMBAHASAN}

Berikut disajikan data yang merupakan hasil pemilihan sampel untuk penelitian ini dengan menggunakan teknik purposive sampling. 


\section{Tabel 1.}

\section{Hasil Pemilihan Sampel Penelitian}

\begin{tabular}{lc}
\hline Kriteria & Jumlah Perusahaan \\
\hline Perusahaan yang melakukan akuisisi periode 2011-2016 & 319 \\
Perusahaan akuisitor yang belum terdaftar di BEI & $(245)$ \\
Perusahaan yang melakukan corporate action lain & $(3)$ \\
Perusahaan yang tidak memiliki data lengkap & $(7)$ \\
Perusahaan yang sesuai dengan kriteria & $\mathbf{6 4}$ \\
Sampel yang mengandung data outlier & $(14)$ \\
Perusahaan akuisitor yang menjadi sampel & $\mathbf{5 0}$ \\
\hline
\end{tabular}

Sumber: Data diolah, 2017

Berdasarkan tabel 1, dapat diketahui bahwa jumlah populasi pada penelitian yaitu sebanyak 319 perusahaan yang melakukan merger dan akuisisi pada tahun 2011-2016, namun terdapat 245 perusahaan yang belum terdaftar di Bursa Efek Indonesia, 3 perusahaan yang melakukan corporate action lain, dan 7 perusahaan yang tidak memiliki data yang lengkap yang tidak sesuai dengan kriteria pemilihan sampel dan 14 perusahaan yang merupakan data outlier sehingga menghasilkan 50 sampel perusahaan.

Hasil uji normalitas data yang akan diuji adalah sampel keseluruhan yang berjumlah 50 perusahaan. Berdasarkan hasil pengujian, nilai K-S untuk peristiwa Cumulative Abnormal Return (CAR) sebelum pengumuman adalah 1,244 dengan nilai signifikansi 0,090 yang nilainya diatas kriteria 0,05 yang berarti peristiwa sebelum pengumuman berdistribusi normal. Nilai K-S untuk peristiwa Cumulative Abnormal Return (CAR) sesudah pengumuman adalah 1,319 dengan nilai signifikansi 0,062 yang nilainya diatas kriteria 0,05 yang berarti peristiwa sesudah pengumuman berdistribusi normal. Sedangkan normalitas data untuk variabel volume perdagangan saham yaitu nilai K-S untuk peristiwa Average Trading Volume Activity (ATVA) sebelum pengumuman adalah 1,307 dengan nilai signifikansi 0,066 yang nilainya diatas kriteria 0,05 yang berarti peristiwa 
sebelum pengumuman berdistribusi normal. Nilai K-S untuk peristiwa Average Trading Volume Activity (ATVA) sesudah pengumuman adalah 1,139 dengan nilai signifikansi 0,149 yang nilainya diatas kriteria 0,05 yang berarti peristiwa sesudah pengumuman berdistribusi normal.

Analisis statistik deskriptif disajikan dengan tujuan untuk dapat memberikan informasi umum tentang gambaran karakteristik sampel yang berupa nilai tertinggi, nilai terendah, standar deviasi, dan rata-rata. Hasil analisis deskriptif yang akan diuji untuk variabel penelitian Cumulative Abnormal Return (CAR) dan variabel penelitian Average Trading Volume Activity (ATVA) yang sudah dikurangi data outlier berjumlah 50 sampel perusahaan. Hasil analisis deskriptif sampel penelitian dapat dilihat pada tabel 1 dan 2 .

Tabel 2.

Statistik Deskriptif Variabel Cumulative Abnormal Return (CAR)

\begin{tabular}{cccccc}
\hline Variabel & Jumlah & Minimum & Maksimum & Rata-Rata & $\begin{array}{c}\text { Std. } \\
\text { Deviation }\end{array}$ \\
\hline CAR Sebelum & 50 & $-0,1126$ & 0,3450 & $-0,00177$ & 0,0675 \\
CAR Sesudah & 50 & $-0,2272$ & 0,1926 & $-0,02105$ & 0,0522 \\
\hline Sumber: Data diolah, 2017 & & & &
\end{tabular}

Tabel 2 menjelaskan nilai minimum, maksimum, rata-rata, dan standar deviasi sebelum dan sesudah pengumuman akuisisi. Berdasarkan tabel 4.4 nilai Cumulative Abnormal Return (CAR) sebelum pengumuman menunjukkan ratarata sebesar $-0,00177$ dengan standar deviasi (SD) sebesar 0,0675. Nilai tersebut memiliki rata-rata negatif, hal ini berarti bahwa selama 5 hari sebelum pengumuman akuisisi investor cenderung memiliki reaksi negatif dalam pembelian saham perusahaan. Nilai CAR sebelum pengumuman terendah adalah 
sebesar -0,1126 dan nilai CAR sebelum pengumuman tertinggi adalah sebesar 0,3450 .

Nilai Cumulative Abnormal Return (CAR) sesudah pengumuman menunjukkan rata-rata sebesar -0,02105 dengan standar deviasi (SD) sebesar 0,0522. Nilai tersebut memiliki rata-rata negatif, hal ini berarti bahwa selama 5 hari sesudah pengumuman akuisisi investor cenderung memiliki reaksi negatif dalam pembelian saham perusahaan. Nilai CAR sesudah pengumuman terendah adalah sebesar -0,2272 dan nilai CAR sesudah pengumuman tertinggi adalah sebesar 0,1926 .

Tabel 3.

Statistik Deskriptif Variabel Average Trading Volume Activity (ATVA)

\begin{tabular}{cccccc}
\hline Variabel & Jumlah & Minimum & Maksimum & Rata-Rata & $\begin{array}{c}\text { Std. } \\
\text { Deviation }\end{array}$ \\
\hline ATVA Sebelum & 50 & 0,00000 & 0,003467 & 0,000628 & 0,000700 \\
ATVA Sesudah & 50 & 0,00000 & 0,003021 & 0,000625 & 0,000631 \\
\hline \multicolumn{2}{l}{ Sumber: Data diolah, 2017 }
\end{tabular}

Berdasarkan tabel 3 nilai Average Trading Volume Activity (ATVA) sebelum pengumuman menunjukkan rata-rata sebesar 0,000628 dengan standar deviasi (SD) sebesar 0,0007. Nilai ATVA sebelum pengumuman terendah adalah sebesar 0,00000 dan nilai ATVA sebelum pengumuman tertinggi adalah sebesar 0,003467 .

Nilai Average Trading Volume Activity (ATVA) sesudah pengumuman menunjukkan rata-rata sebesar 0,000625 dengan standar deviasi (SD) sebesar 0,000631. Nilai ATVA sesudah pengumuman terendah adalah sebesar 0,00000 dan nilai ATVA sesudah pengumuman tertinggi adalah sebesar 0,003021. Ratarata volume perdagangan saham sebelum pengumuman akuisisi menunjukkan 
angka lebih besar daripada sesudah pengumuman akuisisi. Hasil analisis ini menunjukkan bahwa dengan adanya pengumuman akuisisi volume perdagangan saham mengalami penurunan.

Hipotesis 1 dalam penelitian ini adalah terdapat perbedaan cumulative abnormal return yang diperoleh investor pada saat sebelum dan sesudah pengumuman akuisisi. Hasil pengujian perbedaan abnormal return sebelum dan sesudah pengumuman akuisisi ditunjukkan dalam tabel 4.6.

Tabel 4.

Hasil Uji Paired T-Test Variabel Abnormal Return

\begin{tabular}{cccccc}
\hline Variabel & Jumlah & t-hitung & $\begin{array}{c}\text { Sig } \\
\text { (2-Tailed) }\end{array}$ & Kriteria & Keterangan \\
\hline $\begin{array}{c}\text { CAR Sebelum- } \\
\text { Sesudah }\end{array}$ & 50 & 2,399 & 0,020 & 0,05 & Signifikan \\
\hline $\begin{array}{l}\text { Sumber: Data diolah, } 2017 \\
\text { Sumbera }\end{array}$ & & & &
\end{tabular}

Berdasarkan tabel 4, abnormal return sebelum dan sesudah pengumuman akuisisi menunjukkan nilai signifikansi sebesar 0,020. Nilai signifikansi dibawah 0,05 menunjukkan bahwa adanya perbedaan yang signifikan. Sehingga dapat disimpulkan bahwa hipotesis diterima, hal ini berarti terdapat perbedaan abnormal return sebelum dan sesudah pengumuman akuisisi atau dengan kata lain bahwa pengumuman akuisisi memiliki kandungan informasi sehingga investor bereaksi terhadap informasi pengumuman akuisisi.

Hipotesis 2 dalam penelitian ini adalah terdapat perbedaan rata rata volume perdagangan saham yang diperoleh investor pada saat sebelum dan sesudah pengumuman akuisisi. Hasil pengujian perbedaan rata-rata volume perdagangan saham sebelum dan sesudah pengumuman akuisisi ditunjukkan dalam tabel 5. 
Tabel 5.

Hasil Uji Paired T-Test Variabel Volume Perdagangan Saham

\begin{tabular}{cccccc}
\hline Variabel & Jumlah & t-hitung & $\begin{array}{c}\text { Sig } \\
\text { (2-Tailed) }\end{array}$ & Kriteria & Keterangan \\
\hline $\begin{array}{c}\text { ATVA Sebelum- } \\
\text { Sesudah }\end{array}$ & 50 & 0,053 & 0,958 & 0,05 & $\begin{array}{c}\text { Tidak } \\
\text { Signifikan }\end{array}$ \\
\hline
\end{tabular}

Sumber: Data diolah, 2017

Berdasarkan tabel 5, volume perdagangan saham sebelum dan sesudah pengumuman akuisisi menunjukkan nilai signifikansi sebesar 0,958. Nilai signifikansi diatas 0,05 menunjukkan adanya perbedaan yang signifikan. Sehingga dapat disimpulkan bahwa hipotesis ditolak, dimana hal ini berarti tidak terdapat perbedaan volume perdagangan saham sebelum dan sesudah pengumuman akuisisi atau dengan kata lain bahwa pengumuman akuisisi tidak memiliki kandungan informasi sehingga investor bereaksi terhadap informasi pengumuman akuisisi.

Penelitian dengan menggunakan event study pada peristiwa pengumuman akuisisi, menunjukkan bahwa peristiwa pengumuman akuisisi ini memiliki kandungan informasi yang menyebabkan pelaku pasar bereaksi terhadap peristiwa tersebut. Hasil pengujian menunjukan terdapat perbedaan abnormal return sebelum dan sesudah pengumuman akuisisi. Hasil ini sesuai dengan hipotesis 1 (H1). Nilai rata-rata Cumulative Abnormal Return (CAR) sebelum pengumuman adalah -0,00177 dan nilai rata-rata Cumulative Abnormal Return (CAR) sesudah adalah -0,02105, hasil ini menunjukkan nilai CAR sebelum pengumuman lebih tinggi daripada CAR sesudah pengumuman. Penurunan abnormal return setelah pengumuman akuisisi signifikan karena pasar menganggap pengumuman akuisisi mengandung informasi negatif untuk perusahaan akuisitor tersebut. 
Hasil penelitian ini mendukung teori sinyal dan teori pasar efisien dimana sinyal pengumuman akuisisi telah membuat pasar bereaksi dan nilai saham yang diperdagangkan merefleksikan semua informasi yang dalam hal ini adalah pengumuman akuisisi. Beberapa hasil penelitian lain juga mendukung hasil penelitian ini diantaranya, penelitian Kards, et al. (2011), Rani dan Kadav (2013), Asti Rumondang (2010), Ulfi Maryati (2012), Nike Astria (2013), Epriyeni dan Kharlina (2013) dan Dhitta Ayu Lestari (2014).

Penelitian dengan menggunakan event study pada peristiwa pengumuman akuisisi, menunjukkan bahwa peristiwa pengumuman akuisisi ini memiliki kandungan informasi yang menyebabkan pelaku pasar bereaksi terhadap peristiwa tersebut. Hasil pengujian menunjukan bahwa tidak terdapat perbedaan secara signifikan pada volume perdagangan saham sebelum dan sesudah pengumuman akuisisi pada perusahaan akuisitor. Hasil ini tidak sesuai dengan hipotesis 2 .

Nilai rata-rata Average Trading Volume Activity (ATVA) sebelum pengumuman adalah 0,000628 dan nilai rata-rata Average Trading Volume Activity (ATVA) sesudah pengumuman adalah 0,000625, hasil ini menunjukkan nilai ATVA sebelum pengumuman lebih tinggi daripada ATVA sesudah pengumuman. Penurunan volume perdagangan saham setelah pengumuman akuisisi tidak signifikan. Hasil penelitian ini menunjukkan bahwa pengumuman akuisisi tidak berpengaruh secara signifikan terhadap pengambilan keputusan investasi yang tercermin pada volume perdagangan saham. Hal ini kemungkinan dapat disebabkan karena para investor sudah mengetahui terlebih dahulu mengenai adanya informasi akuisisi sehingga menyebabkan investor tertarik 
membeli saham sebelum tanggal notifikasi akuisisi. Selain itu dapat disebabkan karena investor menganggap sinergi perusahaan memberikan sinyal negatif untuk perusahaan akuisitor sehingga para investor menunda keputusannya untuk membeli saham. Beberapa penelitian sebelumnya mendapatkan hasil yang sama dengan hasil penelitian ini, diantaranya Edward (2012), Maryati 2012), dan Pratama (2015) yang menyatakan bahwa tidak terdapat perbedaan volume perdagangan saham sebelum dan sesudah pengumuman akuisisi.

\section{SIMPULAN}

Berdasarkan atas hasil pembahasan, dapat ditarik beberapa simpulan, sebagai berikut: terdapat perbedaan yang signifikan abnormal return sebelum dan sesudah pengumuman akuisisi pada perusahaan-perusahaan akuisitor yang terdaftar di BEI dan tidak terdapat perbedaan yang signifikan volume perdagangan sebelum dan sesudah pengumuman akuisisi pada perusahaan-perusahaan akuisitor yang terdaftar di BEI.

Berdasarkan hasil analisis dan simpulan, maka saran yang dapat diberikan kepada penelitian selanjutnya, yaitu agar dapat meneliti kembali dengan menggunakan variabel tujuan perusahaan ketika melakukan akuisisi untuk melihat bagaikan reaksi pasar dan memperpanjang tahun pengamatan untuk mendapatkan data lebih banyak agar mendapat hasil penelitian yang lebih representatif. Bagi emiten, penelitian ini diharapkan dapat sebagai masukan dan pertimbangan sebelum melakukan keputusan akuisisi agar mendapatkan respon yang baik dari pasar. Bagi calon investor, diharapkan penelitian ini dapat menjadi satu masukan atau pertimbangan sebelum melakukan investasi di pasar modal berdasarkan atas 
satu keputusan yang dikeluarkan emiten, khususnya melakukan pembelian atau penjualan saham diluar tanggal event window pengumuman akuisisi.

\section{REFERENSI}

Amit, Raphael, Joshua Livnat \& Paul Sharon. 1989. A Classification of Mergers and Acquisitions by Motives: Analysis of Market Responses. Contemporary Accounting Research, 6(1), pp: 143-158.

Andriani, Ni Luh Ayu Dessy dan Ida Bagus Anom Purbawangsa. 2016. Dampak Akuisisi PT Agung Podomoro Land, Tbk Terhadap Reaksi Pasar Sektor Properti Bursa Efek Indonesia. E-Jurnal Manajemen Unud, 5(1), h: 414442.

Ang, Robert. 2010. Buku Pintar: Pasar Modal Indonesia. Edisi Ketujuh. Jakarta: Mediasoft Indonesia.

Aryasa, I Putu Gde Chandra Artha. Reaksi Pasar Sebelum Dan Sesudah Pengumuman Right Issue. Skripsi: Universitas Udayana.

Astria, Nike. 2013. Analisis Dampak Pengumuman Merger Dan Akuisisi Terhadap Abnormal Return Saham Perusahaan Akuisitor yang Terdaftar di BEI Tahun 2006-2008. Skripsi: Universitas Brawijaya.

Bahtera, Kusnan. 2014. Pengujian Efisiensi Setengah Kuat Terhadap Pengumuman Merger dan Akuisisi. Skripsi: Universitas Negeri Semarang.

Brigham, Eugene F. dan Houston, Joel F. 2011. Dasar-dasar Manajemen Keuangan, Edisi 11. Jakarta: Salemba Empat.

Brigham, Eugene F. dan M. C. Ehrhardt. 2011. Financial Management: Theory and Practical. $13^{\text {th }}$ Edition. South Western: Cengange Learning.

Dananjaya, Ida Bagus Gede dan Ni Luh Putu Wiagustini. 2015. Studi Komparatif Abnormal Return Sebelum dan Sesudah Merger Pada Perusahaan di BEI. E-Jurnal Manajemen Unud 4(4), h: 1085-1099.

Edward, M. Yunies. 2012. Analisis Reaksi Pasar atas Pengumuman Merger dan Akuisisi. Jurnal Dinamika Ekonomi \& Bisnis 9(1), h: 1-16. 
Fama, Eugene. 1970. Efficient Capital Markets - A Review of Theory and Empirical Work. Journal of Finance, 25(2), h: 383-417.

Ghozali, H. Imam. 2016. Aplikasi Analisis Multivariate dengan Program IBM SPSS 23. Edisi Kedelapan. Semarang: Badan Penerbit Universitas Diponegoro.

Harpern, Paul. 1983. Corporate Aqcuisition: A Theory of Special Cases? A Review of Event Studies Applied to Acquisitions. The Journal of Finance 38, h: 297-317.

Hartono, Jogiyanto. 2015. Teori Portofolio dan Analisis Investasi. Edisi Kesepuluh. Yogyakarta: BPFE Yogyakarta.

-----. 2010. Teori Portofolio dan Analisis Investasi. Edisi Ketujuh. Yogyakarta: BPFE Yogyakarta.

Hidayat, Ali Sulas. 2013. Reaksi Pasar Modal Indonesia Terhadap Kenaikan Harga Bahan Bakar Minyak (BBM) 22 Juni 2013 (Studi Peristiwa pada Perusahaan yang Terdaftar di Indeks LQ-45, Perusahaan Sektor Manufaktur dan Perusahaan Sektor Pertambangan). Skripsi Universitas Gadjah Mada.

Husnan, Suad. 2009. Dasar-Dasar Teori Portofolio dan Analisis Sekuritas. Edisi Keempat Yogyakarta: UPP AMP YKPN.

Indarti dan Purba, D. M. BR. 2011. Analisis Perbandingan Harga Saham dan Volume Perdagangan Saham Sebelum dan Sesudah Stock Split. Jurnal Aset 13(1), h: 57-63.

Kashiramka, Smita dan Rao N.V. Mudhalihar. 2013. Shareholders Wealth Effects of Mergers \& Acquisitions in Different Deal Activity Periods in India. European Journal of Business and Management, 5(4), h: 116-129.

Komisi Pengawas Persaingan Usaha. Daftar Perusahaan yang Melakukan Merger dan Akuisisi di Indonesia tahun 2010-2017: http://www.kppu.go.id. Diakses pada 4 September 2017.

Kuncoro, Wahyu Hadi. 2014. Analisis Pengaruh Merger dan Akuisisi Terhadap Kinerja Keuangan Perusahaan (Studi Kasus Pada Perusahaan yang Terdaftar di Bursa Efek Indonesia Periode 2004-2013). Skripsi: Universitas Diponegoro Semarang. 
Lestari, Dhitta Ayu. 2014. Analisis Perbandingan Abnormal return dan Volume Perdagangan Saham Sebelum dan Setelah Merger dan Akuisisi (Studi Kasus: Perbankan yang Terdaftar di BEI, Periode 2008-2013). Skripsi: Universitas Diponegoro.

Liargovas, Panagiotis. 2010. The Impact of Mergers and Acquisitions on the Performance of the Greek Banking Sector: An Event study Approach. International Journal of Economics and Finance, 3(2): h: 89-100.

Mar'ati, Fudji Sri. 2012. Analisis Efisiensi Pasar Modal Indonesia. Jurnal Ilmu Manajemen Dan Akuntansi Terapan (JIMAT), 3(2), h: 35-44.

Maryati, Ulfi. 2012. Pengaruh Pengumuman Merger Bursa Efek Jakarta dan Bursa Efek Surabaya Terhadap Harga dan Volume Perdagangan. Jurnal Akuntansi \& Manajemen 7(1), h: 15-29.

McWilliams A. dan Siegel D. 1997. Event Studies in Management Research: Theoretical and Empirical Issues. Academy of Management Journal 40(3), h: 626-657.

Moin, Abdul. 2010. Merger, Akuisisi dan Divestasi. Edisi 2. Yogyakarta: Ekonisia

Nanggala, Andhree Prasetiya. 2009. Reaksi Pasar Terhadap Pengumuman Akuisisi pada Saham Perusahaan Akuisitor (Perbandingan Akuisisi dengan Menggunakan Metode Pembayaran Kas dan Saham). Skripsi Fakultas Ekonomi Universitas Airlangga, Surabaya.

Nugroho, Muhammad Aji. 2010. Analisis Perbandingan Kinerja Keuangan Perusahaan Sebelum dan Sesudah Merger dan Akuisisi (Pada Perusahaan Pengakuisisi, periode 2002-2003). Skripsi Universitas Diponegoro Semarang.

Nur Arifin, Hanafi. 2015. Pengujian Efisiensi Pasar Modal Bentuk Setengah Kuat Secara Informasi terhadap Peristiwa Merger dan Akuisisi. Skripsi Sarjana Akuntansi pada Fakultas Ekonomi Universitas Negeri Yogyakarta.

Nurviani, Novi. 2013. Gelombang Merger Melanda: Bangga atau Waspada?: http://www.kppu.go.id/id/blog/2013/01/gelombang-merger-melandabangga-atau-waspada/. Diakses 27 November 2017.

Peraturan Pemerintah Republik Indonesia No. 57 Tahun 2010 tentang Penggabungan atau Peleburan Badan Usaha dan Pengambilan Saham 
Perusahaan yang Dapat Mengakibatkan Terjadinya Praktek Monopoli dan Persaingan Usaha Tidak Sehat: http://www.peraturan.go.id. Diakses pada 1 September 2017.

Pernyataan Standar Akuntansi Keuangan (PSAK) No. 22 tentang Kombinasi Bisnis.

Pratama, Andika Putra, Sendhang \& Nurseto Saryadi. 2015. Analisis Perbedaan Harga Saham, Volume Perdagangan Saham, Return Saham Sebelum dan Sesudah Informasi Rencana Akuisisi PT. Bank Tabungan Negara (Persero) Tbk. oleh PT. Bank Mandiri (Persero) Tbk. Jurnal Administrasi Bisnis Universitas Diponegoro 4(2), h: 1-13.

Pujonggo, Hilarion Didik. 2004. Pengujian Efisiensi Pasar Bentuk Setengah Kuat Secara Keputusan: Analisis Pengumuman Akuisisi dan Merger Back Door Listing, Akuisisi dan Merjer Perusahaan Publik-Privat dan Akuisisi dan Merjer Perusahaan Publik-Publik. Tesis Universitas Gadjah Mada, Yogyakarta.

Rachmawati, Eka Nuraini, dan Eduardus Tandelilin. 2001. Pengaruh Pengumuman Merger dan Akuisisi terhadap Return Saham Perusahaan Target di Bursa Efek Jakarta. Jurnal Riset Akuntansi dan Ekonomi 1(2) h: 153-170.

Rahmayanti, Dini. 2015. Analisis Reaksi Pasar Terhadap Pengumuman Merger dan atau Akuisisi (Studi Kasus pada Perusahaan-Perusahaan yang Terdaftar di Efek Syariah Periode Tahun 2012-2014). Skripsi: Universitas Islam Negeri Sunan Kalijaga Yogyakarta.

Restanti, Yuke. 2015. Analisis Dampak Pengumuman Akuisisi Terhadap Abnormal Return, Volume Perdagangan Saham dan Risiko Sistematis Pada Perusahaan yang Terdaftar di BEI.

Rumondang, Asti. 2010. Analisis Dampak Pengumuman Merger dan Akuisisi Terhadap Abnormal Return Saham Perusahaan (Studi Pada Bursa Efek Indonesia Periode Tahun 2000-2006). Skripsi Fakultas Ekonomi Universitas Sebelas Maret, Surakarta.

Rusnanda, Eliya Wahyu dan Pardi. 2013. Analisa Pengaruh Pengumuman Merger dan Akuisisi Terhadap Abnormal Return Saham Bank Umum di Bursa Efek Indonesia. MM. Graduasi 29, h: 89-101. 
Seleuh, E. Akben dan A. Altiok Yilmaz. 2011. The Impacts of Mergers and Acquisitions on Acquires Performances: Evidane from Turkey. Bussiness and Economics Journal volume 2011: BEJ-22 E-ISSN: 21516219, h:1-8.

Setyawan, A. 2005. Pengaruh Akuisisi Terhadap Abnormal Return dan Kinerja Perbankan. Skripsi: Universitas Katolik Soegijapranata, Semarang.

Shah, Priyanka dan Parvinder Arora. 2014. M\&A Announcements and Their Effect on Return to Shareholders: An Event Study. Accounting and Finance Research 3(2), h: 170-190.

Sugiyono. 2009. Metode Penelitian Kuantitatif Kualitatif dan R\&B. Bandung: Alfabeta.

2012. Metode Penelitian Kuantitatif Kualitatif dan R\&B. Bandung: Alfabeta.

Tandelilin, Eduardus. 2010. Analisis Investasi dan Manajemen Portofolio. Edisi Ketujuh. Yogyakarta: BPFE Yogyakarta.

Thomson Financial, Institute of Mergers, Acquisitions and Alliances (IMAA) Analysis: https://imaa-institute.org/

Van Dijk, Leon. 2011. Are There Abnormal Return for The Acquires in Mergers and Acquisitions: An Empirical Study for the United States Financial Sector. Period: 07/2005-07/2010.

Wibowo, Amin dan Yulita Milla Pakereng. 2001. Pengaruh Pengumuman Merger Dan Akuisisi terhadap Return Saham Perusahaan Akuisitor dan Non Akuisitor Dalam Sektor Industri yang Sama di Bursa Efek Jakarta. Jurnal Ekonomi dan Bisnis Indonesia, 16(4), h: 372-387. 